\title{
The Investigation of the Education Philosophy of the Education Faculty Students of Yuzuncu Yil University with the $Q$ Method $^{\mathrm{i}}$
}

\author{
Gürol Zirhlioğlu, ${ }^{1, *}$, Ahmet Yayla ${ }^{2}$ \\ ${ }^{1}$ Measurement and Evaluation Department, Education Faculty, Yuzuncu Yil University, Turkey \\ ${ }^{2}$ Program Development Department, Education Faculty, Yuzuncu Yil University, Turkey
}

Copyright $\bigcirc 2016$ by authors, all rights reserved. Authors agree that this article remains permanently open access under the terms of the Creative Commons Attribution License 4.0 International License

\begin{abstract}
Educational philosophy views that effect to the basic elements of education related to concept, principles, beliefs and attitude that being implemented in education. Educational philosophy adopted by the teacher candidates is important in their professional lives for attitude of the education. In this study, perennialism, essentialism, progressivism and reconstructionism that are the basic principles of the education philosophy were transformed into a variety of questions. These questions being with "If I were a teacher" and we tried to identify what the level of participation of the students to these questions is. The data used in this study was obtained from the students that they are studying in different departments in education faculty of Yuzuncu Yil University. Q method which aimed at measuring the viewpoints, ideas, beliefs, behaviors and inclinations of individuals was used in the analysis of data. This method investigates also differences within sampling with the factor analysis and in particularly, it is an ideal method of measuring of perception of raised against any case. In this study, there are 30 questions. For this reason, the +4 , -4 scale was defined as a Q string to parse the views of students. This scale was designed from strong agree $(+)$ to strong disagree (-).
\end{abstract}

Keywords Q Method, Perennialism, Essentialism, Progressivism, Reconstructionism

\section{Introduction}

Educational perception and teacher's education perspective are the essential factors that affect quality of education. When relationship between student and teacher is considered, educational belief of teacher strikes a chord on students [21]. Without answering for what reason, how and what kind of a human will be trained, materialization of education is unlikely impossible. Purpose of education and the issues that must be taught to reach to this purpose constitute the basis of philosophy of education [1].

Teaching styles of teacher, which might be affected by philosophy of education, can directly or indirectly affect learning process and success of a student [17]. Philosophy of education is an essential factor that directs education, interrogates the system again at every turn and repairs failing sides of education like a living organism. Human intellection takes part in the fundamentals of education systems. Besides evaluating these intellections, philosophy of education examines a lot of assumptions that deal with education politics and their implementation. By evaluating current education system, it constitutes new hypothesis that will direct education [7]. According to Ozmon and Craver (1981) the purpose of the philosophy of education is to enable to think about what educators do and to be able to see and notify in individual and social development context [2].

According to Çoban, education and learning activities and their methods of application, behavioral perspectives, causes and outcomes are only achieved in functional mental environments and philosophical movements. Philosophies of education have different perspectives and shape the educational environment with respect to philosophy of education perspective which is considered as basis [3].

Teacher candidates' observation of how a relationship between philosophy and education can be established, what are the contributions that philosophy provides to education theory and implementation that will provide prosperous declinations to their professional life. On the other hand, knowing philosophy of education will help teacher candidates to see the relationship between philosophical movements and purpose, function, program and methods of education. In other words, understanding the philosophical movements and intellection of philosophy of education by 
teacher candidates, will help them to make a healthy decision and improve interrogator perspectives in education theory and implementation. Intellections of philosophy of education that again teacher candidates hold, will contribute the fundamentals of analyzing in a broader perspective of fundamental basis of their own information and results while implementing those information. Philosophical intellection that teacher candidates have will be able to provide them to go around educational lifestyles, facts or events more profoundly, to interrogate and reconsideration on making decisions. Education nature of philosophical intellection, possible purposes, problems and ideas on implementations will be provide teacher candidates for better understanding of education, on the other hand, it will provide a basis for teacher candidates to take true decisions after making healthy evaluations, in the other respects, it will provide important declinations about determining and solving possible problems that are seen or might be seen in education field [18].

Even a little change that might occur in the structure of philosophy of education can cause change in arguments of system. For this reason, academic workers and administrators of a school who constitute the basis of education must internalize philosophy that constitutes the basis of education activities and use the scientific methods besides philosophy in implementation. So and so, importance of the issue becomes more specifically, when it is considered how personal philosophy of education is effective in preparation of education programs that are implemented in schools and constitutes the most important factor of education activities $[5,13]$.

A teacher candidate who is trained with a big care, has his or her own education intellection, purpose that aimed to education and future of education and targets. When these instruments are gathered, teacher starts to think about reality, human nature and society and when all of these are developed in time, teachers' philosophy of education is formed [8]. Teachers' philosophy of education can affect to their own learning style in a vast scale. This situation can directly or indirectly be determinant factor on students' learning process and success [17].

Philosophical thought adventure has a long past. From antiquity to nowadays, a lot of philosopher produced very valuable remark and idea in this thinking adventure. Ideas that philosophers alleged profoundly affected education like it affected all living quarters. In addition to remarks and proposals about education that philosophers revealed, basic philosophical doctrines such as idealism, realism, pragmatism and existentialism, form basis for emergence of philosophy of education. Intellections of philosophy of education that is converted to practical in education implementation of each philosophical doctrine pioneered to take form of education systems. Particularly, intellection of philosophy of education constitutes the theoretic basis of education programs. Also, preferred philosophy of education for determination of targets, selection of content, regulation of learning and teaching livings, making healthy and consistent evaluations will be found in its background. Especially, institutional basis of the curricula are formed by these the philosophies of education perspectives. In this context, briefly stating the four basic philosophy of education and their implications about education will be beneficial.

\subsection{Perennialism}

Advocates of perennialism consider universe with its spiritual sides, they consider the position of human in the universe metaphysically. School that is not a copy of life is the place where culture is handed down to next generation, is constituted by society and aims to improve human's mental capacity [9]. Perennialism that takes classic idealism and realism as basis is the most radical among philosophy of education movements. Absolute constant in education, according to perennialism, cares universal principles and traditions. There are constant absolute truths in the universe and human nature is also constant. Perennialism of intellection of philosophy of education that reflects this determinedness principle to education, asserts education should be formed according to absolute, constant and quality of universal principles. Information and moral doesn't change according to time and society, this universal constant values are handed down to next generation via education that is process of preparation of individuals to life. According to perennialism, training a durable and character-wise human is the most important basic purposes of education. Other purpose of education is to improve human mind that is the most important side of human nature and ability of thinking and to teach human to use mind according to logical principles. For this reason, one of the main duties of schools is to educate rational human and to train over wise individuals. In this context, teacher as a model to its student in all fields and is an expert in its field, takes responsibility in the point of demonstrating the ways of logical and consistent thinking. Classic arts constitute the focus point of the program, which takes Perennialism philosophy of education as basis. Particularly, in this intellection, where humanities are put courses forward such as literature, philosophy, history, sociology, logic and linguistic are important. Program is issue based and information that constitutes the content is accurate and constant. Issues should be chosen to reflect universal truth $[1,7,9,12,13,15,18]$.

\subsection{Essentialism}

Essentialism that is a traditional philosophy of education, is based on realism and idealism, defends human as a social and cultural existence. Human nature that doesn't have any information since birth, gets the information via reasoning way independent from cultural and historical structures. Information that is obtained via reasoning are absolute truths. The duty of school is to convey these truths to students. 
According to essentialism that adopts issue based education intellection, core of education is constituted by very good internalization of issue field. The child goes to school in order to recognize and interpret the world [7, 13]. Purpose of education is socialization of society by handing down the knowledge and cultural heritage to next generations, training informed and talented people. Teacher is responsible for handing down of information and cultural heritage and socialization process of students. Traditional methods that are based on abstract thinking in education are used and mostly teacher based in the process of learning and teaching [21]. Essentialism that defends the necessity of strengthens of the authority of teacher in classroom cares hard and repressive discipline intellection in education. School is managed via hierarchical order. In order to preserve authority and provide external discipline, gift and punishment can be given to students. Student memorizes whatever transferred and answers whenever asked. According to essentialism, basic skills such as reading, writing and counting, courses such as science and history take part in the focal point of the program $[16,20]$.

\subsection{Progressivism}

Progressivism is the implementation of pragmatism to the education, in opposition to perennialism and essentialism; it centers changing to the education by refusing constant and universal truths. According to the progressivism that approves education as a process of improvement and changing, trainer should adopt to changing life and environment conditions. In this intellection, education that is approved as a process in which experiences are constantly restructured, should teach constantly changing life. Content should be constantly reviewed according to changing conditions, information that constitute content should be updated. Progressivism is opposed to traditional education system, which is based on strict discipline and stylistic, teacher centered. Progressivism that puts forward student based intellection [9], since it opposes to obtaining the information as intangible and transferring it from teacher to student, it defends necessity of active attendance of students to the process and learning via problem solving and improving projects. Duty of the teacher is guiding to the student by preparing education environment $[9,13,18]$.

According to progressivism, besides school prepares to the life, it is the life itself. For this reason, school rather than forcing students to compete, it promotes solidarity and collaboration. Since school is considered as a small sample of society, democracy culture should be earned to students in schools. In order to make students' decisions by themselves and manage themselves, establishment of democratic education environment is important according to progressivism. Environments should be established which will provide students' natural development by their personal interests, expectations and talents. Regulation of activities that can improve abilities of critical thinking and interrogation is another prominent factor of progressivism [9,
$13,20]$.

\subsection{Reconstructionism}

Reconstructionism, which is a follow-up of progressivism and based on pragmatism, states that some scientific and technological developments is a cause for cultural crisis and education is a mediator for elimination of this crisis. For this purpose, society should be reconstituted by the way of education. Instead of national, religious, gender discriminations, values like peace, love and tolerance should be cared. School and education should be a tool for social reforms. For that reason, students should be made believe in the need for social reforms. Democracy should dominate all whole society. [7, 9, 14].

Reconstructionism, which adopts that education is a tool for reconstitution of the society and implementation of social reforms $[7,20]$, argues that the main responsibility for changing the society belongs to teachers. Teacher, who is the representative of change and social reforms, should firstly believe that he/she could change and convert society, then he/she should make the students believe in it. Classroom environment should be democratic. Pluralism and the colors of different cultures should be reflected to the school curricula. In other words, all cultural elements and values in society should be present in the curriculum. Teacher should respect all cultural elements and help student realize the problems. Reconstructionism, which cares the critical thinking and the use of scientific methods by students, defend that equality of opportunity in education needs to be reconceptsualised [13].

In this study, the preferences of prospective teachers about philosophy of education will be tried to be determined and the presence/absence of significant differences between philosophies of educations will be tested by Q method. In Demir and Kull, Q method, which is used in the analysis of data obtained from this study, is described by Brown (1980) as a research method that is used for the measurement of perspective, idea, religion, behavior and regard of a person in terms of subjectivity. In a typical study of $\mathrm{Q}$ method, statements, which will be directed to individuals, are ordered according to a graded index called Q index. Q index provides scientific data by using the personal views of participants [4]. In the process of the analysis, principle components analysis and factor analysis are used. Q method is used to explain the relationship between participants instead of relation of the method is to aim to summarize the available perspectives between participants [22]. It is thought that investigation of prospective teachers' preferences for philosophy of education by $\mathrm{Q}$ method can add a different dimension to the issue.

While teachers perform their jobs, all of their preferences, decisions and evaluations are shaped according to their preferred philosophy of education understanding, in the process of "from theory to implementation". Determination of prospective teachers' preferences for philosophy of education understanding will provide us valuable 
information to predict their future displayed or adopted education/training implementations. In other words, determination of prospective teachers' preferences for philosophy of education will give clues for their future educational activities and adopted educational understandings.

Determination of what kinds of philosophy of education perspective of prospective teachers have upon their graduation is important since their perspective of future teaching can be predicted. in addition, our study is significant for giving due importance to this issue during the training of prospective teachers and for the creation of awareness. The aim of this study is to determine the philosophy of education preferences of prospective teachers at the Faculty of Education at Yuzuncu Yil University (YYU). For this purpose, the answer for the following question has been looked for:

At what level do students at YYU adopt different philosophy of education understandings?

\section{Material and Method}

\subsection{Sampling}

Data used in this study were determined depending on chance by the answers given by students of the Faculty of Education at Yüzüncü Yil University. Research was done with a total of 30 individuals comprising 15 males and 15 females.

\subsection{Data Collection Tool}

In this study, basic principles of philosophy of education movements were used as the data collection tool $[7,9,13$, 20]. These principles were determined as total 30 principles, which include 7 principles of Perennialism, 7 principles of Essentialism, 9 principles of Progressivism, 9 principles of Reconstructionism. Q index was generated in the range of -4 and +4 . Principles of philosophy of education were turned into sentences beginning with the statement "If $I$ were $a$ teacher..." and they were printed onto numbered cards. Q index for the 30 printed principles is as indicated below:

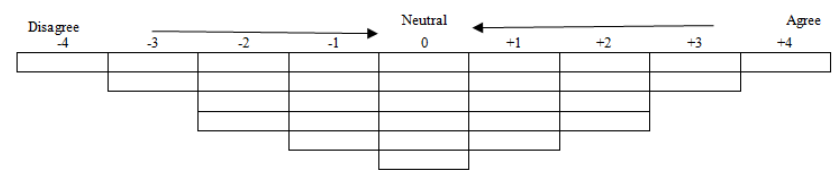

Figure 1. Q index of the study

As seen in Figure 1, students who attended the study were requested to put 1 card to +4 and -4 level, 2 cards to the +3 and -3 level, 4 cards to +2 and -2 level, 5 cards to +1 and -1 level and 6 cards to zero level. After students completed this process, numbers on the cards were recorded cards for each student so that the views of participants were tried to be filtered as much as possible. In addition, students were asked why they prefer the statements they put at +4 and -4 level and they were asked for writing their explanation.

\subsection{Data Analysis}

After data is obtained, their analysis was completed by coding them to Q method program which can be downloaded free from the Internet (http://schmolck.userweb.mwn.de/qmethod/\#PQMethod).

\section{Findings}

According to the principal component analysis performed on data obtained from the study, it was observed that data was clustered under one dimension. This dimension explains $41 \%$ of the variance. The clustering of data under one dimension indicates that there is no difference between male and female students in terms of philosophy of education.

The results for the analysis of significance levels of views that are directed to the participants during the study about the philosophy of education movements were obtained as indicated in Table 1: 
Table 1. Results for Analysis of Views on Philosophy of Education Movements

\begin{tabular}{|c|c|c|c|c|}
\hline $\begin{array}{l}\text { Question } \\
\text { number }\end{array}$ & Statements & No & Factor & Priority no \\
\hline 1 & I make my students gain timeless universal values & 1 & -0.45 & 22 \\
\hline 2 & I make my students read classics which belong to all humanity & 2 & -0.48 & 23 \\
\hline 3 & I prepare my students to life by education & 3 & 0.07 & 16 \\
\hline 4 & I make an effort to raise my students as character-wise and well-behaved individuals & 4 & 1.19 & 3 \\
\hline 5 & I help my students for their cognitive developments and sober behaviors & 5 & 0.67 & 9 \\
\hline 6 & $\begin{array}{l}\text { I make my students gain knowledge and values which are valid for every time and } \\
\text { everywhere instead of the ones important for specific times }\end{array}$ & 6 & 0.56 & 12 \\
\hline 7 & I use Socratic management in learning-teaching process & 7 & -0.42 & 21 \\
\hline 8 & $\begin{array}{l}\text { I make an effort to be the only authority to manage learning-teaching process, to make } \\
\text { decisions, to determine classroom rules }\end{array}$ & 8 & -2.04 & 29 \\
\hline 9 & I adopt a strict discipline understanding for students' learning during the process & 9 & -2.06 & 30 \\
\hline 10 & $\begin{array}{l}\text { I transfer the basic knowledge and background to the students by preserving their important } \\
\text { parts }\end{array}$ & 10 & -0.29 & 19 \\
\hline 11 & I make myself central since I consider classes and topics as important & 11 & -1.56 & 27 \\
\hline 12 & I use traditional methods which are based on abstract thinking & 12 & -1.76 & 28 \\
\hline 13 & I care the transfer of traditional values and cultural heritage & 13 & -0.30 & 20 \\
\hline 14 & I help my students for their cognitive developments and I raise them as talented individuals & 14 & 0.63 & 10 \\
\hline 15 & In instruction, I manage the process by making my students in the center & 15 & 1.11 & 4 \\
\hline 16 & $\begin{array}{l}\text { I strongly oppose the view that "Knowledge should be obtained in an abstract way and } \\
\text { knowledge should be loaded into the minds of students by teacher." }\end{array}$ & 16 & 0.70 & 8 \\
\hline 17 & $\begin{array}{l}\text { I provide my students to be active by making the understanding of learning by experience } \\
\text { central. }\end{array}$ & 17 & 1.95 & 1 \\
\hline 18 & $\begin{array}{l}\text { I form a basis for a democratic classroom environment by making the decisions for classroom } \\
\text { management with my students }\end{array}$ & 18 & 1.37 & 2 \\
\hline 19 & I use problem-solving method in learning-teaching process. & 19 & 0.13 & 14 \\
\hline 20 & I guide my students for the issues for which they need help. & 20 & 0.61 & 11 \\
\hline 21 & I work for the raise my students' suspicious and critical thinking & 21 & 0.98 & 5 \\
\hline 22 & I make a basis for my students' collaborative learning without a competition between them & 22 & 0.73 & 7 \\
\hline 23 & I make an effort for the development of democratic and social life. & 23 & 0.11 & 15 \\
\hline 24 & I work for reconstruction of the society and establishment of the real democracy & 24 & -0.20 & 18 \\
\hline 25 & I work for changing and converting society and putting social reforms into practice & 25 & -0.15 & 17 \\
\hline 26 & I pioneer for the establishment of a new social structure and lead my students for this purpose. & 26 & -0.87 & 26 \\
\hline 27 & I believe that the basic responsibility for social changing belongs to me. & 27 & -0.75 & 25 \\
\hline 28 & I become the representative of the change and social reform. & 28 & -0.58 & 24 \\
\hline 29 & $\begin{array}{l}\text { I behave like the coordinator of the learning-teaching process and head of the project and I } \\
\text { help my students realize their problems }\end{array}$ & 29 & 0.34 & 13 \\
\hline 30 & I care for the propagation of equality and opportunity in education. & 30 & 0.76 & 6 \\
\hline
\end{tabular}

In Table 1, importance of each statement with respect to participants is present. Statement 17, "I provide my students to be active by making the understanding of learning by experience central" has the first priority according to participants. The statement, which has the second priority for students, is "I form a basis for a democratic classroom environment by making the decisions for classroom management with my students". On the contrary, statement 9, which is "I adopt a strict discipline understanding for students' learning during the process" has the least priority.

After the statements were analyzed, their orders and the degree of agreements for each statement are obtained as in Table 2: 
Table 2. Students' philosophy of education perspectives and the agreement degrees

\begin{tabular}{|c|c|c|c|}
\hline No & Statements & $\begin{array}{l}\text { Philosophy of } \\
\text { education }\end{array}$ & $\begin{array}{l}\text { Agreement } \\
\text { Degree }\end{array}$ \\
\hline 17 & $\begin{array}{c}\text { I provide my students to be active by making the understanding of learning by experience } \\
\text { central. }\end{array}$ & Progressivism & 4 \\
\hline 18 & $\begin{array}{l}\text { I form a basis for a democratic classroom environment by making the decisions for classroom } \\
\text { management with my students }\end{array}$ & Progressivism & 3 \\
\hline 4 & I make an effort to raise my students as character-wise and well-behaved individuals & Perennialism & 3 \\
\hline 15 & In instruction, I manage the process by making my students in the center & Progressivism & 2 \\
\hline 21 & I work for the raise my students' suspicious and critical thinking & Progressivism & 2 \\
\hline 30 & I care for the propagation of equality and opportunity in education. & Reconstructionism & 2 \\
\hline 22 & I make a basis for my students' collaborative learning without a competition between them & Progressivism & 2 \\
\hline 16 & $\begin{array}{l}\text { I strongly oppose the view that "Knowledge should be obtained in an abstract way and } \\
\text { knowledge should be loaded into the minds of students by teacher." }\end{array}$ & Progressivism & 1 \\
\hline 5 & I help my students for their cognitive developments and sober behaviors & Perennialism & 1 \\
\hline 14 & I help my students for their cognitive developments and I raise them as talented individuals & Essentialism & 1 \\
\hline 20 & I guide my students for the issues for which they need help. & Progressivism & 1 \\
\hline 6 & $\begin{array}{l}\text { I make my students gain knowledge and values which are valid for every time and everywhere } \\
\text { instead of the ones important for specific times }\end{array}$ & Perennialism & 1 \\
\hline 29 & $\begin{array}{l}\text { I behave like the coordinator of the learning-teaching process and head of the project and I } \\
\text { help my students realize their problems }\end{array}$ & Reconstructionism & 0 \\
\hline 19 & I use problem-solving method in learning-teaching process & Progressivism & 0 \\
\hline 23 & I make an effort for the development of democratic and social life. & Progressivism & 0 \\
\hline 3 & I prepare my students to life by education & Perennialism & 0 \\
\hline 25 & I work for changing and converting society and putting social reforms into practice & Reconstructionism & 0 \\
\hline 24 & I work for reconstruction of the society and establishment of the real democracy & Reconstructionism & 0 \\
\hline 10 & $\begin{array}{l}\text { I transfer the basic knowledge and background to the students by preserving their important } \\
\text { parts }\end{array}$ & Essentialism & -1 \\
\hline 13 & I care the transfer of traditional values and cultural heritage & Essentialism & -1 \\
\hline 7 & I use Socratic management in learning-teaching process & Perennialism & -1 \\
\hline 1 & I make my students gain timeless universal values & Perennialism & -1 \\
\hline 2 & I make my students read classics which belong to all humanity & Perennialism & -1 \\
\hline 28 & I become the representative of the change and social reform & Reconstructionism & -2 \\
\hline 27 & I believe that the basic responsibility for social changing belongs to me & Reconstructionism & -2 \\
\hline 26 & I pioneer for the establishment of a new social structure and lead my students for this purpose. & Reconstructionism & -2 \\
\hline 11 & I make myself central since I consider classes and topics as important & Essentialism & -2 \\
\hline 12 & I use traditional methods which are based on abstract thinking & Essentialism & -3 \\
\hline 8 & $\begin{array}{l}\text { I make an effort to be the only authority to manage learning-teaching process, to make } \\
\text { decisions, to determine classroom rules }\end{array}$ & Essentialism & -3 \\
\hline 9 & I adopt a strict discipline understanding for students' learning during the process & Essentialism & -4 \\
\hline
\end{tabular}

When the information shown in Table 2 is examined, it was determined that positive views of students are mostly related to progressivism. Some students present an opinion for perennialism, essentialism and reconstructionism. Here, the conspicuous factor is that the statements about reconstructionism are considered in negative view part. If these statements are examined, it can be observed that they are associated with social change and reforms.

The statement of "I provide my students to be active by making the understanding of learning by experience central" is the one which students support at the highest level $(+4)$. On the contrary, the statement of "I adopt a strict discipline understanding for students' learning during the process" is the one which students support at the lowest level (-4).

When the students were asked why they agree with these statements at +4 and -4 levels, the findings below are obtained:

ZD (Turkish Teaching, $3^{\text {rd }}$ grade student, female):

For +4 level: "I think that students will be educated better by learning by experience method."

For -4 level: "Through all my life, I haven't lived as a strict-disciplined person and it is not very difficult to imagine the troubles that the people who always experiences strict rules. Of course, discipline is needed, but it should be moderate. More than moderate will create a difficult process for the students." 
TB (Turkish Language Teaching, $3^{\text {rd }}$ grade student, female):

For +4 level: "I don't agree, because these methods make students passive. In order to obtain a effective instruction the methods and techniques used in the classroom should be student-centered."

For -4 level: "For a more effective education, I support that methods and techniques, which are related to students' lives and in which students can participate, should be used. In brief, the more a student is kept active in a class, the more the aim is achieved."

NT (Primary School Teaching, $4^{\text {th }}$ grade student, female): For +4 level: "A student learns more effectively in a process in which he/she is more active, since this method will provide that the student will realize this knowledge is for himself/herself and it is not restricted to templates. Now that education, teaching and all the process are for the student, the student's activity in this process is natural and correct."

For -4 level: "In order to develop a learning, i.e. an effective learning, process, students need an environment in which they love the process and are motivated in it rather than pressure and strict rules. An opposite situation may result in irritation and demotivation."

YY (English Language Teaching, $3^{\text {rd }}$ grade student, female):

For +4 level: "I think a person only fins out "the truth" by questioning. By others guidance, he/she will never be able to reach the "the best". We must questions. We should start questioning by questioning ourselves first."

For -4 level: "Strict discipline rules force students into rote learning and individuals who are unlikely to questioning and criticism are raised."

SÖ (Primary School Teaching, $4^{\text {rd }}$ grade student, female): For +4 level: "To my view, good and strong character is more important than cognitive success. I value the universal moral."

For-4 level: "I do not think students can learn by using a strict discipline rules. On the contrary, students will be irritated by such an education method."

TG (Music Teaching, $2^{\text {nd }}$ grade student, female):

For +4 level: "The sentence me positive; therefore I stated it in +4 ."

For -4 level: "This statement does not appeal to me."

SA (Science Teaching, $4^{\text {rd }}$ grade student, female):

For +4 level: "I believe that student cannot join learning process when he/she is not active. The student becomes active via learning by experience method so that permanent learning is achieved."

For - 4 level: "Learning cannot be achieved by strict discipline method. Students become passive if teacher apply pressure to the students."
MT (Art Teaching, $3^{\text {rd }}$ grade student, male):

For +4 level: "Whether it is about education or about other topics students should always be taken into consideration to some extent."

For -4 level: "Compulsory education of the students is never right and students are needed to be considered during education."

MG (Turkish Language Teaching, $3^{\text {rd }}$ grade student, male):

For + 4 level: "In order to provide better understanding and application of student"

For -4 level: "I think that traditional education approach rust students"

TK (Turkish Language Teaching, $3^{\text {rd }}$ grade student, male): For +4 level: "I think students will enjoy more when they experience the learning process instantaneous and the learning will be persistent. It provides an opportunity for the development of empathy and ability to think and it prepares for a more realistic life."

For -4 level: "Because, by using instruction, rote learning and traditional methods, the knowledge will not be permanent and these make student bored in educational system; furthermore, make students similar and some-type person and prevents creative thinking.."

AT (English Language Teaching, $3^{\text {rd }}$ grade student, male): For +4 level: "Since I agree and consider as positive" For -4 level: "An opinion that I never agree"

VŞ (English Language teaching, $3^{\text {rd }}$ grade student, male): For +4 level: "I think that student should be central in learning process and he/she should join this process with all the sense organs."

For -4 level: "In classroom setting, teacher's role should be transferred from authority to facilitator."

KA (Biology Teaching, $4^{\text {rd }}$ grade student, male):

For +4 level: "In order to make the student understand his/her life"

For -4 level: "In order to develop their self-esteem."

EÖ (English Language Teaching, $2^{\text {nd }}$ grade student, male): For +4 level: "Education and everything will be presented best in democracy"

For -4 level: "I do not believe that a strict discipline method can be beneficial in learning process"

BD (English Language Teaching, $2^{\text {nd }}$ grade student, male) For +4 level: "Since I think it will be good for students' education"

For -4 level: "As I didn't get it appropriate. I didn't place it there."

SA (Music teaching, $2^{\text {nd }}$ grade student, male):

For +4 level: "Students with strong moral and character will be effective citizens of the society."

For -4 level: "Strict discipline alienates the student from learning process. The student starts to prejudge the class and the teacher." 


\section{Discussion}

The data obtained in this study, which is performed in order to determine how much the students of the Faculty of Education at YYU adopt different philosophy of education perspectives, explains the $41 \%$ of the total variance and it clustered all the data under one dimension.

In the study, it was observed that students adopt progressivism, which is a philosophy of modern education, positively. For this philosophy of education, it is observed that they care the statement of "I provide my students to be active by making the understanding of learning by experience central" mostly. Ekiz, states that prospective teachers agree with all the items of progressivism with a high arithmetic mean of agreement degree and opinion in favor for this view is at the forefront. In the same study, the statement of "Since learning will occur by experience within the principles of progressivism, students should be offered rich-learning experiences." has the highest average [6]. This situation shows parallelism in both studies. It is observed that, apart from progressivism, other philosophies of education are also present and perennialism is the predominant one. This situation shows that students are also affected by traditional philosophies of education along with philosophies of modern education. In Karadağ et al., in a study done in 2006, Küken states that education has a part related to values, however it should possess a free part for future's developing and such a system of education can be present via a multi-dimensional philosophy of education understanding [10]. If the general structure of Turkish education system is examined, it is expected to be traditional and dependent on traditional values while it should be innovative at the same time. Therefore, it can be thought that the goals of education represent all four philosophies of education [14].

In this study, students who chose the extreme values of $Q$ index, +4 and -4 , were asked to explain the reasons for their preferences and they were asked for a written explanation. The statement that students chose at +4 level is "I provide my students to be active by making the understanding of learning by experience central". The reasons for this preference can be summarized as follows: more effective education-training process, the fact that students' activity is an important factor to achieve the goals, the fact that learning by experience may increase students' activity, more permanent learning, the fact that prospective teacher's ability to empathize and think will develop, the probability that more than one sense organs can be used. During education process, student should experience prosperous experiences. This situation is going to provide self-development for the student and the opportunity to develop and improve himself/herself. For this purpose, students should be triggered and motivated for learning without forcing and their old experiences should be benefited [13]. Yeşil and Yeşil, states that in learning by experiencing principle, individuals should work both mentally and physically and in this process, which also means the learning process, there should be learning methods that provide production so that the process should be based on learning [20].

On the other hand, the statement that is preferred at the lowest level $(-4)$ by students belongs to essentialism principle and the statement is "I adopt a strict discipline understanding for students' learning during the process". The reasons for this preference of students can be summarized as follows: the probability that extreme discipline may cause a difficult process although moderate discipline is needed, the need for establishing an environment in which students enjoy and are motivated to learn and pressure and strict rules should not be applied to them, the fact that strict rules results in educating individuals without the ability to examine and criticize, the fact that students will be passive, for the development of self-esteem, and the fact that the student will be alienated from the learning process and cause the formation of prejudice. Some of teachers' unfavorable behaviors in the classroom are reprehension, threatening, getting angry easily humiliating, abasing and extreme punishment [14]. Kiroğlu, defines education as liberating the brain, heart and hand of the individual in the direction of sense seeking. Education should expand horizons instead of setting bounds and it should be independent from fear, which may cause the loss of the power of freethinking and abilities [11].

According to the findings obtained in this study, negative views of students are associated with reconstructionism, essentialism and perennialism. Here, one of the conspicuous issues is that students do not adopt reconstructionism, which belongs to philosophies of modern education, at a high level since some of its principles are given negative values. These principles are "I become the representative of the change and social reform", "I believe that the basic responsibility for social changing belongs to me" and "I pioneer for the establishment of a new social structure and lead my students for this purpose." Social change and reform are the common characteristics of these principles. Students who are prospective teachers express negative views about these issues that are related to social sensitivity.

In their studies, Yazar and Yilmaz, state that prospective primary school teachers think that the faculties of education do not have any effects on social transformation for various reasons [19].

\section{Conclusions}

The data obtained in this study which is performed in order to determine how much the students of the Faculty of Education at YYU adopt different philosophy of education perspectives. As a result, it was observed that students mostly support the philosophies of modern education, especially progressivism, but they also adopt traditional philosophies. Additionally, they oppose the views related to essentialism. Another result obtained in this study is that students represent negative opinions for the social transformation related principles of reconstructionism, which belong to philosophies of modern education. 
The results that the learning will be more persistent via learning by experience method and student activity, prospective teachers' ability to empathize will develop and the individual can use all sense organs at the same time were obtained.

It was determined that students do not adopt the idea that strict discipline rules should be applied during learning process. Instead of a strict discipline understanding, they think that environments in which students are motivated and have fun should be established and strict discipline rules might have negative effects on the self-esteem of the students.

Suggestions that can be offered according to the information obtained at the end of the study can be stated as below:

- By deepening the study, different results can be obtained in terms of different variables.

- In order to see the effect of instructors on students, the opinions of instructors and students can be evaluated together.

- Precautions should be taken on the principles of reconstructionism related to social transformation and students should be made have more opinion about teacher's effects on social transformation and development.

- Especially, the problems related to educating teachers in the faculties of education should be focused carefully and importantly.

- In all areas of school teaching, basic sociology and philosophy of education courses should be present.

\section{REFERENCES}

[1] Cevizci, A. (2014). Eğitim Felsefesi. İstanbul: Say Yayınları.

[2] Conti, GJ. (2007). Identifying Your Educational Philosophy: Development of the Philosophies Held by Instructors of Lifelong-learners (PHIL). MPAEA Journal of Adult Education, Volume XXXVI, Number 1, 19-35.

[3] Çoban, A. (2002). Sınıf Öğretmenliği Öğretmen Adaylarının, Eğitim Sürecine İlişkin Felsefi Tercihlerinin Değerlendirilmesi. C.Ü.Sosyal Bilimler Dergisi, 26(2), 311-318.

[4] Demir, F., Kul, M. (2011). Modern Bir Araştırma Yöntemi Q Metodu. Ankara: Adalet Yayınevi.

[5] Doğanay, A., Sarı, M. (2003). İlköğretim öğretmenlerinin sahip oldukları eğitim felsefelerine ilişkin algıların değerlendirilmesi "öğretmenlerin eğitim felsefeleri". Türk Eğitim Bilimleri Dergisi, 1(3), 321-337.
[6] Ekiz, D. (2007). Öğretmen adaylarının eğitim felsefesi akımları hakkındaki görüşlerinin farklı programlar açısından incelenmesi. Ondokuz Mayıs Üniversitesi Eğitim Fakültesi Dergisi, 24, 1-12.

[7] Ergün, M. (2014). Eğitim Felsefesi. Ankara: Pegem Akademi.

[8] Gutek, GL. (1997). Eğitime Felsefi ve İdeolojik Yaklaşımlar. (Çev. Nesrin KALE). Ankara: Pegem Yayıncıllk.

[9] Gutek, GL. (2014). Eğitime Felsefi ve İdeolojik Yaklaşımlar. (Çev. Nesrin KALE). Ankara: Ütopya Yayınevi.

[10] Karadağ, E., Baloğlu, N., Kaya, S. (2009). Okul Yöneticilerinin Eğitim Felsefesi Akımlarını Benimseme Düzeylerine İlişkin Ampirik Bir Çalışma. Uludağ Üniversitesi Felsefe Dergisi, 12, 181-200.

[11] Kıroğlu, K. (2011). Bir Meslek Olarak Öğretmenlik. Ö. Demirel ve Z. Kaya (Ed.), Eğitim Bilimine Giriş içinde (s.346-372).

[12] Kneller, GF., (1964). Introduction to the Philosophy of Education. John Wiley\&Sons, Inc.

[13] Sönmez, V. (2014). Eğitim Felsefesi. Ankara: Anı Yayıncılık.

[14] Şişman, M. (2002). Öğretmenliğe Giriş. Ankara: Pegem A Yayıncilık.

[15] Tozlu, N. (1997). Eğitim Felsefesi, Ankara: MEB.

[16] Tuncel, G. (2004). Öğretmenlerin Kendi Eğitim Felsefelerini İnşa Etmeleri Üzerine. Kazım Karabekir Eğitim Fakültesi Dergisi, 10, 223-242.

[17] Yapıcı, Ş. (2013). Öğretmen ve Öğretmen Adaylarının Eğitim Felsefeleri. Turkish Studies-International Periodical for the Languages, Literature and History of Turkish or Tukic,8(8), p.1431-1452.

[18] Yayla, A. (2014). Eğitim Felsefesi Temelleri. H.B. Memduhoğlu ve K. Yılmaz (Ed.), Eğitim bilimine giriş içinde (s.21-46). Ankara: Pegem Akademi.

[19] Yazar, T., Yılmaz, F. (2013). Sınıf Öğretmenliği Adaylarının Yeniden Kurmacılık Eğitim Felsefesi Çerçevesinde Eğitim Fakülteleri ve İlkokulların Toplumsal Dönüşüm Rollerine İlişkin Görüşleri. XII. Ulusal Sınıf Öğretmenliği Eğitimi Sempozyumu Bildiriler Kitab1, 422-429, 23-25 Mayıs 2013, Aydin. (www.academia.edu/8149047, Access date: 05.06.2014)

[20] Yeşil, R., Yeşil, S. (2013). Öğretim İlk eve Yöntemleri. Ankara: Sonçağ Yayıncılık.

[21] Y1lmaz, K., Tosun, MF. (2013). Öğretmenlerin Eğitim İnançları ile Öğretmen Öğrenci İlişkilerine Yönelik Görüşleri Arasındaki İlişki. Eğitim ve Öğretim Araştırmaları Dergisi, 2(4), p.205-218.

[22] Zabala, A. (2014). Q method: A Package to Explore Human Perspective Using Q Methodology. The R Journal, Vol. 6/2, 163-173.

\footnotetext{
Oral presentation in International Conference on New Horizons in Education, Barcelona, 2015
} 